\title{
The influence of customer expectations, customer loyalty, customer satisfaction and customer brand loyalty on customer purchasing intentions: A case study of K-POP fans in Thailand
}

\author{
Adisak Suvittawat \\ School of Management Technology, Institute of Social Technology, Suranaree University of Technology, \\ Nakhon Ratchasima Province, Thailand.
}

Received 19 October, 2021; Accepted 29 December, 2021

\begin{abstract}
From 1992 on the K-Pop culture has spread from South Korea all over the world and Thailand is no exception. The objective of this study was to analyze the variables that influence purchasing intentions of K-Pop fans in Thailand in terms of customer expectations, customer loyalty, customer satisfaction and customer brand loyalty. The four hundred thirty-one Thai respondents provided great insights into the purchasing intentions of Thai K-Pop fans in terms of theoretical and practical applications. Overall, the customers were very satisfied with the artists and exhibited a high brand loyalty to the products endorsed by the K-Pop groups. The Korean performers met the expectations of their followers which also let them to be loyal to their favorite boy or girl group. Understanding Thai Korean Pop music fans and their purchasing behavior helps the artist to capitalize on their influence through product endorsement and advertisement contracts which in turn are based on ratings of the artists in the before mentioned categories. It is hoped to replicate this study in the future in other ASEAN countries and other parts of the world.
\end{abstract}

Key words: brand loyalty, customer expectations, customer loyalty, customer satisfaction, K-POP artists, purchasing intentions.

\section{INTRODUCTION}

Since 1992 K-Pop (Korean: 케이팝; RR: keipap), culture has been taking over Asia and the world. It was then when the South Korean group Seo Taiji and Boys started to create a repertoire that integrated English lyrics, eclectic dance styles, and hip-hop elements with their South Korean roots with a mild western undertone. The modern K-pop "idol" culture that spread as the Korean Wave; over Southeast Asia, to India and Pakistan and from there to the Middle East and Africa, and throughout Europe the USA and the Western world, gaining a broad international audience. 2020 was a record-breaking year for K-Pop when it experienced almost a fifty percent growth and became the fastest-growing music market of the year, with BTS and BLACKPINK as the leading idol groups. K-Pop fans are going crazy over this new third generation of Korean superstars, which includes

E-mail: Adisak@sut.ac.th. 
MAMAMOO, NCT and Monsta X. (Choi and Maliangkay, 2014). In 2021 more than ever, it has become clear that K-Pop has been on a steady track to globalization. The K-Pop industry uses digital marketing strategies through influencer marketing and very unusual content creation on social network platforms that attract a global audience. The group BTS for instance has over thirty million Instagram followers, who form a loyal fan base, that breaks records on YouTube and iTunes. K-Pop artists also learned how to capitalize on their fame by becoming company spokes persons and endorsing products and brands of all kinds of goods and services on a global basis. The K-Pop groups have created a loyal followership of fans that listen to them and follow their recommendations when it comes to purchasing decisions. Our research study looked at the customer purchasing intentions of K-Pop fans in Thailand and the influences K-Pop artists have in regards to: Customer Expectations, Customer Loyalty, Customer Satisfaction and Customer Brand Loyalty.

\section{REVIEW OF LITERATURE}

A literature review was conducted which explored the various aspect components of influence of customer expectations, customer loyalty, customer satisfaction and social influencers on customer purchasing intentions of K-POP fans in Thailand and explored the K-Pop culture as the underlying force the literature underpinned our research hypotheses in terms of customer expectations, customer loyalty customer satisfaction and brand loyalty the literature review is divided into those sections related to the research hypotheses to spell it out for the reviewers.

Customer expectations are defined to be the futureoriented beliefs about product or service before the consumption as defined by Mark (2015). Martin and Simmons (1999) discussed the phenomenon of prepurchase and post purchase customer expectations. With changing customer expectations customer loyalty is changing as well. Rosen (2018) pointed out the professional judgment differs from that of the customer's expectations. Some companies exceed customer expectations by responding to changing customer expectations and by actively managing the customer expectations (Miller, 2000). But it is necessary to correctly understand and interpret customer expectations which also depend on the cultural aspects according to Overby and Assouad (2016). Kim et al. (2021) explored the success factors and sustainability of the K-Pop Industry with a structural equation model and fuzzy set analysis which helped the research hypotheses.

Customer loyalty as defined by Oliver (1999) is a commitment to re-purchase a certain product or service in the future despite other influences and marketing efforts to potentially cause a switching behavior.
McMullen (2005), developed a scale for measuring customer loyalty development which guided the author research. Wong and Sohal (2003) researched service quality and various customer loyalty perspectives. Customer loyalty programs try to institutionalize customer loyalty (Uncle et al., 2003). Hanifah (2019) looked at customer advocacy as a result of the relationship between idol attachment and customer loyalty in the KPop industry which guided our customer loyalty hypothesis.

Customer satisfaction is the judgment a consumer makes in relation to his sense of fulfillment related to his purchase intentions and use of products and services according to Guido (2015). Maminiaina (2019) provided a thorough literature review of customer satisfaction definitions, factors affecting customer satisfaction and measurement of customer satisfaction. Yi et al. (2021) examined the relationship between customer participation, customer bonding, and customer satisfaction. Gustafsson et al. (2005) linked the effects of customer satisfaction and customer retention leading to brand loyalty. Kim et al. (2018) guided their research hypothesis in terms of customer satisfaction with their study of purchasing behavior of K-pop idol goods consumers in Korea.

Brand loyalty can be seen as a biased behavioral response which will be expressed over time. Loyalty implies a repurchase pattern of the brand which is a result of positive affection towards the brand (Mellens and Steenkamp, 1996).

According to Aaker (1991) brand loyalty is at the core of brand equity. Aggarwal (2004) explored the various effects of brand relationship norms on consumer attitudes and consumption behavior. Alnawas and Shadi, (2015) surveyed the role of brand identification generating higher levels of brand loyalty. Keller (1998) looked at strategic brand management to create brand loyalty. Lee and Kim (2020) explored brand loyalty and the Bangtan Sonyeondan (BTS) Korean dance this underpinned their research hypothesis in relation to brand loyalty.

Social media influencers are heavy social media users who have established themselves as a trustworthy source in a certain area such as the K-POP scene. Social media influencers have massive audiences and the ability to convince others by virtue of their authenticity such as the K-POP groups and their fans. Influencers can genuinely influence the behavior of their group of followers. Influencers regularly post about on the various social media channels and thereby generate large followings of passionate zealous people who pay close attention to their perspective. Saboo et al. (2016) measured the impact of social media activities on various brand sales.

K-Pop culture is an example of engineering the customer experience as defined by Carbone and Haeckel (1994). Capistrano (2019) conducted a study to understand Filipino Korean Pop Music Fans. Seo (2012a) focused on the lessons from K-Pop's global success. And 


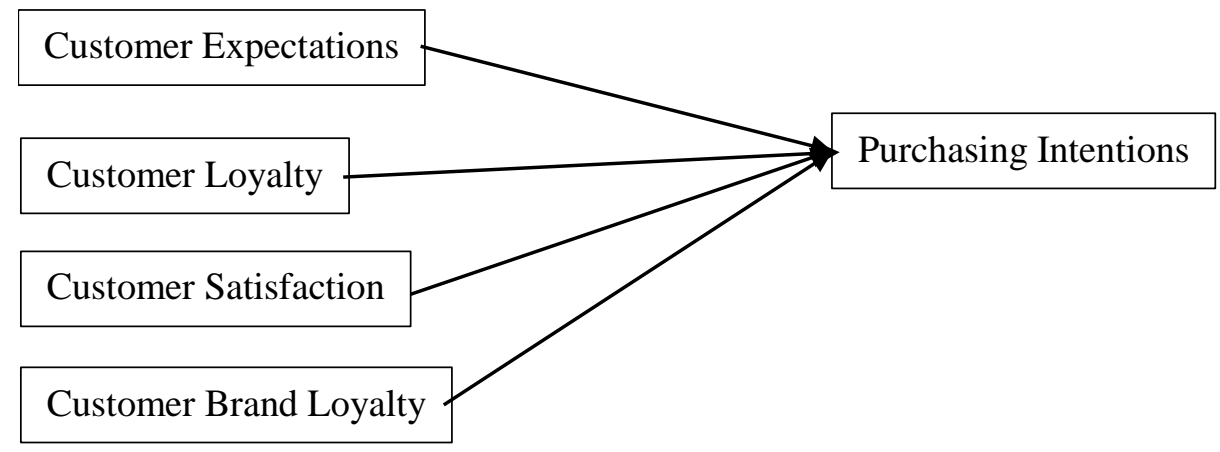

Figure 1. Conceptual research framework.

in Seo (2012b) he looked at what the corporate world can learn from K-Pop in terms of global strategy. Alanzalon (2011) shaped the word Kpopped in the study that researched Filipino teens' consumption of Korean popular videos, dance and music. Chen (2016) created a framework for marketing cultural exports and used it to analyze Hallyu (the Korean Wave). Igno and Cenidoza (2016) tried to understand Hallyu in the Philippines. Choi and Maliangkay (2015) studied fandom and the international rise of K-Pop. Choi (2011) questioned if KPop is losing its Korean-Ness due to the globalization of the genre. Decrop and Derbaix (2014) researched the artist-related determinants of concert prices including KPop. Doherty (1987) also explored the role of MTV and music videos in the promotion efforts. English et al. (1994) focuses on the cultural encoding of beauty types in print and video advertising. Huang (2017) explored social media and the New Korean Wave, and Yoon (2017) also looked at the Korean Wave from a retrospect and prospect perspective. Kim (2017) researched KPop's global popularity as a case of Girls' Generation's USA debut. Oh and Park (2012) moved from B2c to B2b selling of Korean pop music in the age of new social media. Oh and Lee (2013) looked at mass media technologies and the pop music genres while exploring K-Pop and YouTube. Pacis (2012) performed a study on the expanding world of K-Pop fandom as a subculture. Park (2013) saw the production, performance, and dissemination of K-Pop as an example of manufactured creativity. Parc and Moon (2013) explored the key factors for the international competitiveness of Korean TV soap operas and movies as part of the growing K-Pop culture. Figure 1 show the conceptual research framework.

\section{Hypothesis}

Hypothesis 1 (H1): Customer expectations positively influence customer purchasing intentions

Hypothesis 2 (H2): Customer loyalty positively influences customer purchasing intentions

Hypothesis $3(\mathrm{H} 3)$ : Customer satisfaction positively influences customer purchasing intentions.

Hypothesis $4(\mathrm{H} 4)$ : Influencing of influencer on brand loyalty positively influences customer purchasing intentions.

\section{RESEARCH METHODOLOGY}

The research study attempted to apprehend the purchase intentions of K-Pop fans on various magnitudes. The researcher developed a quantitative paper-based survey instrument. The instrument was pretested following ontologies, epistemologies, and methodologies outlined by Decrop (2004). The visitors of K-Pop events were interviewed by the researchers and the results were captured with paper-based instruments in the form of a questionnaire.

\section{Population}

The population of this study consisted of K-Pop fans in Thailand and in particular in Bangkok. As other K-Pop fans are alike and hope to be able to make generalizations. The K-Pop fans followed a variety of Korean boy and girl groups which performed in Thailand.

\section{Sample}

The study focused on K-Pop fans in Bangkok. All participants where Thai nationals, tourists and expats were not part of this study. Table 1 shows that the majority of the participants were female $(76.3 \%)$ and are under the age of thirty years with a bachelor degree or high school education. The random convenience sample included four hundred thirty one respondents interviewed at K-Pop events and the sample demographics were representative of the demographics of the K-Pop fan population in Thailand.

Table 1 show that the majority $(60.6 \%)$ of the participants in the study were employed and had a monthly income of less than 1,200 USD. Almost $14 \%$ earned between 1,201 and 1,800 dollars and $15.5 \%$ earned over 1,800 USD a month. The majority of the respondents came from Bangkok and the surrounding areas of the Metroplex. The sample solicited responses from new K-Pop fans with less than one year $(34.1 \%)$ of fan experience but the majority of participants had between one to three years $(42.7 \%)$ fan experience some respondents had four to six years $(10 \%)$ and $13.2 \%$ even more than six years. In the study Gen $Z$ (teens 13-17) accounted for roughly $10 \%$, Millennials (adults 18-34) for about $75 \%$ - three quarters of the respondents and Generation X (adults 
Table 1. Demographics.

\begin{tabular}{|c|c|c|}
\hline Participants & Count (respondents) & Percentage \\
\hline \multicolumn{3}{|l|}{ Gender } \\
\hline Male & 102 & 23.7 \\
\hline Female & 329 & 76.3 \\
\hline TOTAL & 431 & 100 \\
\hline \multicolumn{3}{|l|}{ Age } \\
\hline$<20$ years & 54 & 12.5 \\
\hline $21-30$ years & 321 & 74.5 \\
\hline $31-40$ years & 53 & 12.3 \\
\hline$>41$ years & 3 & 0.7 \\
\hline TOTAL & 431 & 100 \\
\hline \multicolumn{3}{|l|}{ Income (Monthly) } \\
\hline$<600$ USD & 194 & 45.0 \\
\hline 601-1,200 USD & 91 & 25.6 \\
\hline $1,201-1,800$ USD & 79 & 13.9 \\
\hline$>1,801$ USD & 67 & 15.5 \\
\hline TOTAL & 431 & 100 \\
\hline \multicolumn{3}{|l|}{ Education Level } \\
\hline Lower than undergraduate degree & 282 & 65.4 \\
\hline Undergraduate degree & 83 & 19.2 \\
\hline Graduate degree & 35 & 8.1 \\
\hline Doctorate degree & 31 & 7.1 \\
\hline TOTAL & 431 & 100 \\
\hline \multicolumn{3}{|l|}{ Favorite Band Tracking Experience } \\
\hline Less than 1 year & 146 & 34.1 \\
\hline $1-3$ years & 184 & 42.7 \\
\hline $4-6$ years & 43 & 10 \\
\hline More than 6 years & 58 & 13.2 \\
\hline TOTAL & 431 & 100 \\
\hline
\end{tabular}

Source: author.

$35-49$ years of age) for about $12 \%$.

\section{RESEARCH FINDINGS}

The findings of the study can be categorized as follows by customer expectations, customer loyalty, customer satisfaction and customer brand loyalty following the research hypothesis and research instrument. The following tables summarize the data and the research findings were placed in the research context. The results included both mean and standard deviation (SD) as well as correlation coefficients and regression analysis for the relationship between purchase intentions of K-Pop fans and:

1) Customer expectations
2) Customer loyalty

3) Customer satisfaction

4) Customer brand loyalty

\section{Customer expectations}

Table 2 shows that K-Pop fans as customers strongly agreed that their customer expectations were met on average and on all seven dimensions such as positive attitude towards fans (Mean 4.53 and SD 0.52) was strongly agreed. Artists are constantly improving themselves (Mean 4.51 and SD 0.54) strongly agreed. Artists have a wide range of talents mostly dancing and singing (Mean 4.48 and SD 0.55). Artists are sincere with their fans (Mean 4.38 and SD 0.57) strongly agreed Artists have a close relationship with their fans (Mean 
Table 2. Customer expectations.

\begin{tabular}{|c|c|c|c|}
\hline Variable & Mean & S.D. & Results \\
\hline \multicolumn{4}{|l|}{ Customer expectations } \\
\hline 1. Artists have a positive attitude towards fans & 4.53 & 0.52 & Strongly Agreed \\
\hline 2. Artists are constantly improving themselves & 4.51 & 0.54 & Strongly Agreed \\
\hline 3. Artists have a wide range of talents & 4.48 & 0.55 & Strongly Agreed \\
\hline 4. Artists are sincere with their fans & 4.38 & 0.57 & Strongly Agreed \\
\hline 5. Artists have a close relationship with their fans & 4.29 & 0.66 & Strongly Agreed \\
\hline 6. Artists have good looks and personality & 4.28 & 0.64 & Strongly Agreed \\
\hline 7. Artists have multiple communication channels & 4.23 & 0.67 & Strongly Agreed \\
\hline Average & 4.38 & 0.59 & Strongly Agreed \\
\hline \multicolumn{4}{|l|}{ Customer loyalty } \\
\hline 1. Purchase merchandise promoted by artists & 4.06 & 0.91 & Strongly Agreed \\
\hline 2. Recommending artists to others & 4.03 & 1.00 & Strongly Agreed \\
\hline 3. Twitter trending or vote for artists regularly & 3.76 & 1.18 & Agreed \\
\hline 4. Prioritize members over favorite band & 3.52 & 1.38 & Agreed \\
\hline 5. Attend concerts or Fan meetings regularly & 3.45 & 1.29 & Agreed \\
\hline 6. Willingness to travel to meet artists when they visit Thailand & 3.39 & 1.30 & Agreed \\
\hline 7. Donate money for projects promoted by the artists & 3.26 & 1.24 & Agreed \\
\hline Average & 3.63 & 1.18 & Agreed \\
\hline \multicolumn{4}{|l|}{ Customer satisfactions } \\
\hline 1. Artists public appearances at concerts and fan gatherings & 4.09 & 0.63 & Strongly Agreed \\
\hline 2. Appropriate communication channels with artists & 4.02 & 0.67 & Strongly Agreed \\
\hline 3. Social media apps & 3.98 & 0.75 & Agreed \\
\hline 4. Excellent public relations $(\mathrm{PR})$ & 3.95 & 0.78 & Agreed \\
\hline 5. Promotion campaigns & 3.95 & 0.67 & Agreed \\
\hline Average & 3.99 & 0.70 & Agreed \\
\hline \multicolumn{4}{|l|}{ Artists influencing brand loyalty } \\
\hline 1. I feel proud when I use the product that artists are endorsing & 4.02 & 0.80 & Strongly Agreed \\
\hline 2. Willing to participate in activities that bring you closer to the artist & 3.87 & 1.05 & Strongly Agreed \\
\hline 3. Willing to purchase products that are endorsed by the artist & 3.85 & 0.95 & Agreed \\
\hline 4. Recommend others to buy products that the artist endorses & 3.84 & 0.93 & Agreed \\
\hline 5. Continue purchasing endorsed product even if the product is the same as the regular & 3.83 & 0.96 & Agreed \\
\hline 6. If the product is not available in Thailand, it will be purchased through other channels & 3.59 & 1.16 & Agreed \\
\hline 7. Continue purchase this brand even artists contract expired & 3.43 & 1.05 & Agreed \\
\hline 8. Will continue to purchase products even if the product quality is lower than the expectations. & 3.43 & 1.31 & Agreed \\
\hline Average & 3.73 & 1.02 & Agreed \\
\hline
\end{tabular}

Source: author.

4.29 and SD 0.66) strongly agreed. The artists have good looks and personality (Mean 4.28 and SD 0.64) strongly agreed. Artists have multiple communication channels (Mean 4.23 and SD 0.67 ) strongly agreed. So overall the fans are very happy with their K-Pop groups (Mean 4.38 and SD 0.59).

\section{Customer loyalty}

Table 2 shows K-Pop fans also display a high degree of customer loyalty as expressed in the responses to the following questions. The participants purchase merchandise promoted by their K-pop artists. (Mean 4.06 and SD 0.91) strongly agreed. Recommendation of KPop artists to others (Mean 4.03 and SD 1.00) was also strongly agreed. Twitter trending and voting for artists on a regular basis was only agreed on (Mean 3.76 and SD 1.18) Prioritizing members over favorite band were also agreed upon (Mean 3.52 and SD 1.38). Attending concerts and/or fan meetings on a regular basis was agreed upon (Mean 3.45 and SD 1.29). The willingness 
to travel to meet with the K-Pop artists when they visit Thailand was also agreed upon (Mean 3.39 and SD1.30). Donations of money to projects promoted by artists was agreed upon (Mean 3.26 and SD 1.24) but was the lowest on the list of expressions of customer loyalty of KPop fans. But overall, the respondents agreed to customer loyalty with a mean of 3.63 and a SD of 1.18 .

\section{Customer satisfaction}

Table 2 shows that the K-Pop fans or should they be called customers are very satisfied when it comes to public appearances of their group at concerts and fan gatherings (Mean 4.09 and SD 0.63). The fans are also strongly satisfied with the various communication channels to connect with their artists (Mean 4.02 and SD $0.67)$. The fans also enjoy the various social media apps that have been introduced (Mean 3.98 and SD 0.75) and agreed on this dimension of customer satisfaction. They also were satisfied with the PR campaigns and public relations the artists maintained with their fan base (Mean 3.95 and SD 0.78). And fans were also satisfied with the promotion campaigns of their K-Pop bands (Mean 3.95 and SD 0.67). Overall, the customer satisfaction was agreed upon by the Thai K-Pop respondents (Mean 3.99 and SD 0.70).

\section{Customer brand loyalty}

The following research questions look at the role of the KPop artists as social influencers and creators of brand loyalty through product endorsements. Table 2 shows that the fans feel proud when they use a product that has been endorsed by their favorite artists (Mean 4.02 and SD 0.80 ) and was strongly agreed. They are also more than willing to participate in activities that bring them closer to the artist (Mean 3.87 and SD 1.05) and were strongly agreed upon by the participants. The fans are also willing to purchase the products that are endorsed by the artist (Mean 3.85 and SD 0.95) was agreed upon. They also promote by word of mouth and recommend the products endorsed by the artist to friends and others (Mean 3.84 and SD 0.93) and were agreed upon. The fans even continued purchasing the endorsed products after they found out that these products are the same as the regular products (Mean 3.83 and SD 0.96) and this was agreed upon. And fans even purchase the product through other channels if the products are not yet available in Thailand (Mean 3.59 and SD 1.16) and were agreed upon. Customers even continue to purchase the product after the endorsement contract of the artist expires as form of true brand loyalty (Mean 3.43 and SD 1.05) and were agreed upon by the respondents. The loyalty of the fans goes so far that they will continue to purchase the product even after they found out that the product quality is lower than what they expected (Mean 3.43 and SD 1.31) and was agreed upon by the participants of the study. Overall, the social influence of the K-pop artists was agreed upon by the fans and they also have developed a strong brand loyalty to the endorsed products (Mean 3.73 and SD 1.02).

\section{Correlation coefficient analysis - Purchase intentions}

With the data a correlation coefficient analysis was performed with the correlation coefficient $r$ measuring the strength and direction of a linear relationship between two variables on a scatterplot. Here the value $r=1$ represents a perfect positive correlation and the value $r=$ -1 represents a perfect negative correlation. And +0.30 shows a weak uphill (positive) linear relationship while +0.50 is a moderate uphill (positive) linear relationship and +0.70 a strong uphill (positive) linear relationship and +1.00 represents a perfect uphill (positive) linear relationship.

The requirements for the Pearson correlation coefficient were met: The measurement scale was a ratio. And the variables were almost normally distributed. The association was also linear and there were no outliers in the data collected. The researcher also performed a correlation coefficient analysis which explored the K-Pop fans purchase intention factors which included the following:

1) Gender

2) Age

3) Income

4) Education

5) Customer expectations

6) Customer loyalty

7) Customer satisfaction

8) Social influencer

\section{Correlation analysis}

Table 3 shows the correlation coefficient analysis created rather complicated results with no clear linear relationships. Education (0.135) naturally was a relationship with age and gender also played a role predominantly for females. Income (0.092) and in particular discretionary income also affects the level to which fans can participate. Customer expectations had a relationship (0.242) with age and education (0.197). Customer loyalty depends on customer expectations (0.119). Customer satisfaction was related to age $(0.274)$ income (0.380) and customer expectations (0.314) and the brand equity was depending on gender (0.524) income (0.170), customer expectations (0.207) customer loyalty (0.212) and customer satisfaction (0.257).

\section{Regression analysis $(\mathrm{N}=431)$}

The regression analysis determines the degree to which 
Table 3. Correlation coefficient analysis.

\begin{tabular}{|c|c|c|c|c|c|c|c|c|}
\hline Variable & 1 & 2 & 3 & 4 & 5 & 6 & 7 & 8 \\
\hline 1. Gender & 1.00 & & & & & & & \\
\hline 2. Age & 0.114 & 1.00 & & & & & & \\
\hline 3. Education level & $0.135^{*}$ & $0.143^{*}$ & 1.00 & & & & & \\
\hline 4. Income & $0.092^{*}$ & 0.061 & -0.072 & 1.00 & & & & \\
\hline 5. Customer expectations & 0.085 & $0.242^{* *}$ & $0.197^{* *}$ & 0.064 & 1.00 & & & \\
\hline 6. Customer loyalty & 0.094 & 0.061 & -0.073 & -0.061 & $0.119^{*}$ & 1.00 & & \\
\hline 7. Customer satisfaction & $0.274^{*}$ & -1.00 & 0.44 & $0.380^{* *}$ & $0.314^{* *}$ & $0.110^{* *}$ & 1.00 & \\
\hline 8. Influencing of artists through brand loyalty & $0.524^{*}$ & 0.072 & 0.133 & $0.170^{* *}$ & $0.207^{* *}$ & $0.212^{* *}$ & $0.257^{* *}$ & 1.00 \\
\hline
\end{tabular}

${ }^{*}$ Correlation is significant at the 0.05 level (2-tailed), ${ }^{* *}$. Correlation is significant at the 0.01 level (2-tailed).

Table 4. Regression analysis customer purchasing intentions.

\begin{tabular}{lccc}
\hline \multirow{2}{*}{ Variable } & \multicolumn{3}{c}{ Customer Purchasing Intentions } \\
\cline { 2 - 4 } & $\boldsymbol{\beta}$ & R-Squared & Sig. \\
\hline Customer expectations & $0.340^{* *}$ & 0.172 & 0.000 \\
Customer loyalty & $0.327^{\star *}$ & 0.124 & 0.000 \\
Customer satisfaction & $0.451^{\star *}$ & 0.145 & 0.000 \\
Customer brand loyalty & $0.398^{\star *}$ & 0.121 & 0.000 \\
\hline
\end{tabular}

${ }^{* *} \mathrm{p}<.01$.

the independent variables are associated with any changes to the purchase intentions which is the dependent variable. The coefficients inform us about these changes and p-values let us know if these coefficients are significantly different from zero. The unknown parameters, denoted as a scalar or vector beta $(\beta)$. R-Squared informs us of the proportion of variation in the dependent (response) variable purchase intentions that has been explained by this framework. We don't necessarily discard a model based on a low R-Squared value. The hypothesis testing is a fundamental statistical procedure in research. The hypothesis test evaluated the two mutually exclusive statements about a population in order to determine which statement is best supported by the sample data collected $(\mathrm{N}=431)$. When it can be said that the finding is statistically significant, it is based on the hypothesis test regarding customer expectations, customer loyalty, and customer satisfaction and influencing of artists through brand loyalty. Customer expectations received a beta $(\beta=0.340$ and an $R$-Squared of 0.172 ) and was higher than the customer loyalty with a beta $(\beta=0.327$ and an R-Squared of 0.124$)$ and lower than customer satisfaction with a beta $(\beta=0.451$ and an $\mathrm{R}$-Squared of 0.145 ) while influencing of artists through brand loyalty received a beta $(\beta=0.398$ and an $R$-Squared of 0.121 ) which is shown in Table 4.

\section{DISCUSSION}

The influences of customer expectations, customer loyalty, customer satisfaction and influences of K-Pop artist influencer on brand loyalty resulted to customer purchasing intentions of K-POP artist fans. The following hypothesis was examined.

The customer expectations were met and strongly agreed upon. The K-Pop fans strongly agreed that the KPop artists not only have a wide range of talents both in terms of singing and dancing but they also constantly work on themselves in terms of appearance and personality and display a positive attitude towards their fans. The fans feel to be taken serious by the K-Pop artist and that the love is a two-way street expressed in a close relationship between fans and celebrities.

The customer loyalty ranked lower than customer expectations but was still agreed upon. The fans strongly agreed with the concept of purchasing merchandise promoted by artists. And respondents also strongly agreed with the idea of recommending their favorite performers to others by word of mouth. But the other factors of the survey were only agreed upon such as regularly voting and twitter trending of the K-Pop groups. Also attending fan meetings and life concerts did not rank as high which may be due to the social distancing requirements during covid-19. The willingness and possibility to travel to meet artists in Bangkok was also reduced during the pandemic. Fans were also not that eager to donate money to projects sponsored by the artists, an explanation for that may also be the dire economic situation in Thailand due to the collateral damage caused by the several months of lock-downs.

Customer satisfaction overall was only agreed upon. 
Strongly agreed upon were public appearances of artists at concerts and fan gatherings as well as the communication channels the artists used. Fans love to see their favorite artists in person or on various media. Only agreed upon were social media apps as well as public relations $(\mathrm{PR})$ and promotion campaigns. A good example is the Thai bank Kasikornbank (KBank) which had launched a commercial featuring the K-Pop girl group BLACKPINK. This commercial was aimed at encouraging Gen Zs to use KBank's debit card in order to practice social distancing and most importantly bring contactless payment to the forefront of the shopping experience. BLACKPINK has shared values that truly represented the persona of Gen Zs, the band values individuality, creativity, aspiration and freedom which is so important in these fluid times in Thailand.

Customer brand loyalty was strongly agreed upon when asked if fans feel proud when they use the product that artists are endorsing. The K-Pop fans were also very interested to participate in activities that bring them closer to their favorite artists. But they only agreed upon the following like willingness to purchase products that are endorsed by the artist.

Fans would recommend to others to purchase products K-Pop the artist endorses. Some fans will even continue purchasing endorsed product even if they find out that the Kpopped products are the same as the regular products. Fewer fans will continue to purchase products even if the Kpopped product quality is below their expectations. Some fans will go out of their way and find other channels to purchase K-Pop products that are not yet available in Thailand. A good example is purchasing these products on-line and have them shipped to Thailand. Fans will continue to purchase the endorsed brand even after the K-Pop artist's endorsement contract is expired. This is called true brand loyalty.

\section{Conclusion}

This particular research employed a theoretical research framework derived from an academic and practical consumer behavior discourse on customer purchasing intentions of K-Pop fans. The data collected from four hundred thirty-one Thai respondents was subjected to various statistical tests, including standard deviations, mean, correlation analysis as well as regression analysis. The results of this study suggest that Thai K-Pop fans almost blindly follow their idol which has theoretical and practical implications. Furthermore, the research found that Thai K-Pop fan behavior almost uniformly cuts across age, gender, education and income level. In conclusion these findings present several useful theoretical and practical implications that enhance the overall knowledge of K-Pop's international impact on consumer purchasing intentions. The study confirmed the existing literature discussed earlier and their findings in terms of K-Pop and its development from the early days into the future particularly in Thailand and attempted to add to the Thai dimension to the existing body of literature.

Overall, it can be confirmed that K-Pop artists greatly influence customer expectations, customer loyalty, customer satisfaction and the customer brand loyalty of their fans. Not only when it comes to purchasing their music but also the products they endorse. K-Pop culture is here to stay and is growing all over the world as it speaks not only to the young generations of Asia but the world and gives them hope in the New Normal of covid19.

\section{Recommendations}

Recommendations informed by this study are that K-Pop worldwide will continue to influence customer expectations, customer loyalty, customer satisfaction and customer brand loyalty on customer purchasing intentions like no other artists. The researcher intends to follow up this study over time with a larger sample of followers of various specific boy and girl K-Pop groups. Another suggestion is to apply the same instruments to other towns in Thailand such as Chiangmai, Pattaya and Phuket to see if the rural population various from the one in the capital. It is also recommended to replicate the study with foreigners living and visiting Thailand who may be grouped by country of origin to determine how their purchasing intentions may vary from those of the Thai customers. We also intend to expand the scope of the study and focus on various other aspects of purchasing intentions as well as K-pop fans in other contexts in Thailand and neighboring ASEAN countries such as Myanmar, Laos and Cambodia maybe also Vietnam.

\section{Limitations}

This study like any study is a snapshot in time and is limited to the present time and the current situation in Thailand. Why Thai K-Pop fans may have a lot in common with K-Pop fans in other countries there are also specific characteristics which may limit the transferability. It must further be stated that these findings refer to K-Pop fans and other fan groups may have different dynamics and loyalty factors.

\section{CONFLICT OF INTERESTS}

The author has not declared any conflicts of interests.

\section{REFERENCES}

Aaker DA (1991). Managing Brand Equity. The Free Press, New York. Aggarwal P (2004). The Effects of Brand Relationship Norms on Consumer Attitudes and Behavior. Journal of Consumer Research 
31(1):87-101 .

Alanzalon SM (2011). Kpopped! Understanding the Filipino Teens' Consumption of Korean Popular Music and Videos. Unpublished Undergraduate Thesis.

Alnawas I, Shadi AS (2015). Exploring the Role of Brand Identification and Brand Love in Generating Higher Levels of Brand Loyalty. Journal of Vacation Marketing 22(2):111-128.

Capistrano E (2019). Understanding Filipino Korean Pop Music Fans. Asian Journal of Social Science 47(1):59-87.

Carbone LP, Haeckel SH (1994). Engineering Customer Experiences. Marketing Management 3(3):8-19.

Chen S (2016) Cultural Technology: A Framework for Marketing Cultural Exports-Analysis of Hallyu (the Korean Wave). International Marketing Review 33(1):25-50.

Choi J, Maliangkay R (2014). K-Pop-The international rise of the Korean music industry. Routledge.

Choi JB, Maliangkay R (2015). Why Fandom Matters to the International Rise of K-Pop. In: Choi JB, Maliangkay R (eds.), K-Pop: The International Rise of the Korean Music Industry. New York, NY: Routledge.

Choi YJ (2011). The Globalization of K-Pop: Is K-Pop Losing Its Korean-Ness? Situations 5(1):61-67.

Decrop A (2004). Trustworthiness in qualitative tourism research. In: Phillimore J, Goodson L (eds.), Qualitative research in tourism: Ontologies, epistemologies, and methodologies. London: Routledge. pp. 165-196.

Decrop A., Derbaix M (2014). Artist-Related Determinants of Music Concert Prices. Psychology and Marketing 31(8):660-669.

Doherty T (1987). Mtv and the Music Video: Promo and Product. Southern Journal of Communication 52(4):349-361.

English BG, Solomon MR, Ashmore RD (1994). Beauty before the Eyes of Beholders: The Cultural Encoding of Beauty Types in Magazine Advertising and Music Television. Journal of Advertising 23(2):49-64.

Guido G (2015). Customer satisfaction. Wiley encyclopedia of management. pp. 1-8.

Gustafsson A, Johnson M, Roos I (2005). The Effects of Customer Satisfaction, Relationship Commitment Dimensions, and Triggers on Customer Retention. Journal of Marketing, 69(4):210-218.

Hanifah RN (2019). Customer Advocacy as a result of the relationship between idol attachment and customer loyalty in the K-Pop industry. East African Scholars Journal of Economics, Business and Management 3(2):197-201.

Huang S (2017). Social Media and the New Korean Wave. Media, Culture and Society 39(5):773-777.

Igno JAM, Cenidoza MCE (2016). Beyond the Fad: Understanding Hallyu in the Philippines. International Journal of Social Science and Humanity 6(9):723-727.

Keller KL (1998). Strategic Brand Management, Prentice Hall, Upper Saddle River, New Jersey.

Kim G (2017). Between Hybridity and Hegemony in K-Pop's Global Popularity: A Case of Girls' Generation's American Debut. International Journal of Communication 11(1):2367-2386.

Kim JH, Jung SH, Roh J, Choi HJ (2021). Success Factors and Sustainability of the K-Pop Industry: A Structural Equation Model and Fuzzy Set Analysis. Sustainability 13:5927.

Kim YJ, Lee J, Lee M (2018). Purchasing Behavior of K-pop Idol Goods Consumers in Korea. Journal of Fashion Business 22(6):1-13.

Lee HW, Kim JH (2020). Brand loyalty and the Bangtan Sonyeondan (BTS) Korean dance: Global viewers' perceptions. Journal of Psychology in Africa 30(6):551-558.
Maminiaina AR (2019). A thorough literature review of customer satisfaction definition, factors affecting customer satisfaction and measuring customer satisfaction. International Journal of Advanced Research 7(9):828-843.

Mark T (2015). Using customer expectations to manage project outcomes to ensure success. Available at: https://www.linkedin.com/pulse/using-customer-expectationsmanage-project-outcomes-ensure-tallman

Martin D, Simmons P (1999). Customer Expectations. Journal of Hospitality and Leisure Marketing 6(1):67-81.

McMullen R (2005). A multiple scale for measuring Customer Loyalty development. Journal of Services Marketing 19(7):470-481.

Mellens M, DeKimpe MG, Steenkamp EM (1996). A Review of BrandLoyalty Measures in Marketing. Journal of Economic Management 4:507-533.

Miller HE (2000). Managing Customer Expectations. Information Systems Management 17(2):1-4.

Oh I, Lee HJ (2013). Mass Media Technologies and Popular Music Genres: K-Pop and Youtube. Korea Journal 53(4):34-58.

Oh I, Park GS (2012). From B2c to B2b: Selling Korean Pop Music in the Age of New Social Media. Korea Observer 43(3):365-397.

Oliver LR (1999). When customer loyalty? Journal of Marketing 63(4):33-44.

Overby J, Assouad A (2016). The Impact of Culture on Customer Expectations. Journal of Management Policy and Practice 17(2):1932.

Pacis J (2012). Popping the K-Pop Bubble: A Study on the World of KPop Fandom as a Subculture. University of the Philippines.

Parc J, Moon HC (2013). Korean Dramas and Films: Key Factors for Their International Competitiveness. Asian Journal of Social Science 41(2):126-149

Park GS (2013). Manufacturing Creativity: Production, Performance, and Dissemination of K-Pop. Korea Journal 53(4):14-33.

Rosen R (2018). Professional judgment v customer expectations. BMJ 36

Saboo AR, Kumar V, Ramani G (2016). Evaluating the Impact of Social Media Activities on Human Brand Sales. International Journal of Research in Marketing 33(3):524-541.

Seo MS (2012a). Lessons from K-Pop's Global Success. SERI Quarterly 5(3):60-66.

SeoMS (2012b). What Business Can Learn from K-Pop for Global Strategy. CEO Information, Samsung Economic Research Institute. No. 841.

Uncle MD, Dowling GR, Hammond K (2003). Customer loyalty and customer loyalty programs. Journal of Consumer Marketing, 20(4):294-316.

Wong A, Sohal A (2003). Service quality and customer loyalty perspectives on two levels of retail relationships. Journal of Services Marketing 17(5):495-513.

Yi HT, Yeo C, Amenuvor FE, Boateng H (2021). Examining the relationship between customer bonding, customer participation, and customer satisfaction. Journal of Retailing and Consumer Services 62(1):102598.

Yoon TJ (2017). The Korean Wave: Retrospect and prospect Introduction. International Journal of Communication 11:2241-2249. 